\title{
HOXC13 wt Allele
}

National Cancer Institute

\section{Source}

National Cancer Institute. HOXC13 wt Allele. NCI Thesaurus. Code C97578.

Human HOXC13 wild-type allele is located in the vicinity of 12 q13.13 and is approximately $8 \mathrm{~kb}$ in length. This allele, which encodes homeobox protein Hox-C13, is involved in transcriptional regulation. A translocation $\mathrm{t}(11 ; 12)(\mathrm{p} 15 ; \mathrm{q} 13)$ of this gene and the NUP98 gene is associated with acute myeloblastic leukemia. 